(c) American Dairy Science Association, 2005.

\title{
Influence of Storage and Preservation on Fossomatic Cell Count and Composition of Goat Milk
}

\author{
A. Sánchez, ${ }^{1}$ D. Sierra, ${ }^{2}$ C. Luengo, ${ }^{2}$ J. C. Corrales, ${ }^{1}$ C. T. Morales, ${ }^{2}$ \\ A. Contreras, ${ }^{1}$ and C. Gonzalo ${ }^{3}$ \\ ${ }^{1}$ Departamento de Sanidad Animal, Facultad de Veterinaria, Universidad de Murcia, \\ 30071 Murcia, Spain \\ ${ }^{2}$ Laboratorio Agroalimentario y de Sanidad Animal, Consejería de Agricultura y Agua, \\ Comunidad Autónoma de la Región de Murcia, El Palmar, 30120 Murcia, Spain \\ ${ }^{3}$ Departamento de Producción Animal, Facultad de Veterinaria, Universidad de León, \\ 24071 León, Spain
}

\section{ABSTRACT}

This study was designed to evaluate the effects of different test conditions on the somatic cell count (SCC) and composition of goat milk. To this end, 3600 tests were performed on 1800 aliquots taken from 40 goat milk samples using a combined instrument set-up based on flow cytometry for SCC and Fourier transform infrared analysis for fat, total protein, lactose, total solids, and freezing point determinations. The conditions tested were storage temperature (refrigeration and freezing), use of a preservative [no preservative (NP), azidiol (AZ), and bronopol (BR)], and age of the milk samples at each storage temperature ( $24 \mathrm{~h}$ to $42 \mathrm{~d}$ at refrigeration temperature and 21 to $105 \mathrm{~d}$ at freezing temperature). Significant effects on logSCC variation were shown by the storage temperature, the preservation treatment, the interaction of storage temperature $\times$ preservation treatment, and milk age within the interaction of storage temperature $\times$ preservative. Highest counts were recorded in the BR-preserved milk samples $(\operatorname{logSCC}=$ 5.877), and lowest counts were recorded in milk samples preserved using AZ (logSCC = 5.803). The use of frozen/ thawed samples led to a significantly decreased logSCC for the treatments AZ and NP; the logSCC was not modified when BR-preserved frozen/thawed samples were analyzed. During storage, variations in the SCC observed for BR-preserved samples stored at refrigeration temperature for up to $25 \mathrm{~d}$ and at freezing temperature for all times tested were always $<10 \%$. The preservation treatment was the main factor affecting the milk composition variables examined. Highest values of most variables were obtained in the BR-preserved samples, and the lowest values were obtained in the AZ-preserved samples. The freezing point was lower in the preserved

Received February 11, 2005.

Accepted June 7, 2005.

Corresponding author: A. Contreras; e-mail: acontrer@um.es. samples than in the NP samples. The levels of milk constituents recorded in the BR-preserved samples were independent of both the storage temperature and age of milk sample. Our findings indicate that the freezing point of goat milk must be interpreted according to the preservative used.

(Key words: goat milk, somatic cell count, milk composition, preservation)

Abbreviation key: $\mathbf{A Z}=$ azidiol, $\mathbf{B R}=$ bronopol, $\mathbf{F T}=$ freezing temperature, $\mathbf{N P}=$ no preservative, $\mathbf{R T}=$ refrigeration temperature.

\section{INTRODUCTION}

Efforts to increase the production and quality of goat milk have included genetic and health programs based on monitoring milk variables. The accurate determination of milk constituents is important both to the dairy farmer and to the dairy industry because of economic, health, and management implications. Milk SCC is widely used as a measure of udder health and milk quality. Milk SCC for uninfected goats is higher than SCC for uninfected cows and sheep, and physiological and productive factors have been related to increased goat SCC (Paape et al., 2001). Recently, Luengo et al. (2004) reported the effects of intramammary infections and several non-infection-related factors on the SCC in dairy goats. The goat bulk tank milk SCC has been the target of different legal limits or payment-by-quality schemes proposed by different countries, with obvious repercussions on the marketing of goat milk (Corrales et al., 2004). Because goat milk contains anucleated cytoplasmic particles, only cell-counting procedures specific for DNA should be used to estimate SCC in goat milk (Dulin et al., 1982). In milk-testing laboratories, the DNA-specific fluoro-optical electronic counter is the method most widely used for SCC determination. Factors affecting SCC have been evaluated in cow and sheep milk. In the former, the preservative used (Schmidt Mad- 
sen, 1979; Lee et al., 1986; Barcina, et al., 1987; Vermunt et al., 1995; Bertrand, 1996), the analytical temperature (Miller et al., 1986), the storage temperature (Lee et al., 1986; Barkema et al., 1997), and milk age (Kennedy et al., 1982; Vermunt et al., 1995) have been identified as factors affecting SCC. In sheep milk, recent studies (Gonzalo et al., 2003; Martinez et al., 2003) have established the effects of these factors and their interactions on the accuracy of Fossomatic cell counting, and results have served to optimize the conditions for SCC. In addition, the effects of different temperatures and preservatives on the SCC in sheep milk were recently established for the 2 rapid Fossomatic SCC procedures (based on disk and flow cytometry) most frequently used for processing large numbers of samples in dairy laboratories (Gonzalo et al., 2004). In contrast, only a few investigations have explored the factors affecting the goat milk SCC. Thus, Zeng et al. (1999) reported that the storage of goat milk samples at refrigeration temperature $(\mathbf{R T})$ $\left(5 \pm 1^{\circ} \mathrm{C}\right)$ for $3 \mathrm{~d}$ did not affect the SCC. Horner and Fox (1988) proposed that freezing temperature (FT) was acceptable for SCC in goat milk when a membrane-filter DNA-counting procedure was used. Those researchers, however, did not define the optimal test conditions or preservatives to use. Using a DNA-specific electronic counter (Somacount 300; Bentley Instruments Inc., Chaska, MN), the SCC of goat milk samples preserved with bronopol (BR) were found to be more accurate than counts conducted on unpreserved samples (Arcuri et al., 2004).

Factors affecting milk composition have also been the subject of investigation. Thus, the effects of the container (Bertrand, 1996), the preservative used (Ng-Kwai-Hang and Hayes, 1982; Lee et al., 1986; Barcina et al., 1987; Bertrand, 1996), the storage temperature (Lee et al., 1986; Barcina et al., 1987), and storage time (Ng-KwaiHang and Hayes, 1982; Lee et al., 1986; Barcina et al., 1987) on fat and protein levels have been established in cow milk. However, no such studies have been conducted on goat milk. In dairy laboratories, the use of a combined instrument set-up for SCC and milk composition determinations requires that the test conditions be optimized for determining several variables in the same milk sample. Information on the different methods of preservation, storage temperature, and interactions with storage time could help to optimize analyses. The effects of these factors must also be taken into account for quality control intra- and inter-laboratory comparisons.

The present study was designed to determine the effects of the storage temperature (refrigeration vs. freezing), storage time, and preservative used on the SCC and composition (fat, total protein, lactose, total solids, and freezing point) of goat milk.

\section{MATERIALS AND METHODS}

Murciano-Granadina goats from the same herd were randomly selected for the study. The animals were at different stages of lactation, ranged from 1 to 7 parities, and showed no clinical signs of mastitis. Before routine milking, forty $1100-\mathrm{mL}$ composite milk samples were obtained from the goats selected. Samples were kept at $4^{\circ} \mathrm{C}$ and immediately transported to the laboratory (Laboratorio Agroalimentario y de Sanidad Animal, Murcia, Spain). Immediately after mixing, by inverting 10 times, each sample was divided into forty-five $20-\mathrm{mL}$ aliquots $(n=1800)$, which were then assigned to the experimental groups as shown in Table 1 . The 3 preservative treatments tested were no preservative (NP), azidiol (AZ) $(0.024 \mathrm{~g}$ of sodium azide $/ 100 \mathrm{~mL})$, and bronopol (BR) $(0.04 \mathrm{~g} / 100 \mathrm{~mL}$; Broad Spectrum Microtabs II; D\&F Control Systems, Inc., Dublin, CA). For each preservative treatment, 12 aliquots were stored at RT $\left(4^{\circ} \mathrm{C}\right)$ and 5 were stored at FT $\left(-20^{\circ} \mathrm{C}\right)$. However, for the NP treatment, only 6 aliquots at RT were tested because of spoiling beyond $\mathrm{d} 13$. The storage times tested at RT were, therefore, $24 \mathrm{~h}$ and $3,5,7,10$, and $13 \mathrm{~d}$ for NP and $24 \mathrm{~h}$ and $3,5,7,10,13,16,20,25,31,37$, and 42 $\mathrm{d}$ for $\mathrm{AZ}$ and BR. The times considered at FT were 21, $42,63,84$, and $105 \mathrm{~d}$ for all 3 preservation treatments. Frozen milk aliquots were slowly thawed following a method previously described (Martinez et al., 2003). All of the aliquots were prepared and stored within $5 \mathrm{~h}$ of collection. Before testing, milk aliquots were heated to $40^{\circ} \mathrm{C}$ for $20 \mathrm{~min}$, as this has been defined as the optimal test temperature for sheep milk stored at RT (Gonzalo et al., 2003, 2004) and at FT (Martinez et al., 2003).

Milk composition (fat, total protein, lactose, total solids, and freezing point) and SCC were determined in a CombiFoss 6000 FC instrument (Foss Electric, Hillerød, Denmark), which combines the Milkoscan FT 6000 (Fourier transform infrared analysis) with the Fossomatic FC (flow cytometry somatic cell counter). Before and during the experiments, our equipment was subjected to quality control inter-laboratory tests by a reference laboratory (CECALAIT, Poligny, France). These ring tests involved the use of cow milk standards of known SCC, as there are no standards for goat milk available. In the experiment, the cell counter was adjusted to a slope $(b)=1.00$ and intercept $(a)=0$. All tests were performed in duplicate. The results obtained for the individual samples ranged from $125 \times 10^{3}$ to $4224 \times 10^{3}$ cells/ $\mathrm{mL}, 3.790$ to $8.700 \%, 2.490$ to $4.660 \%, 4.250$ to $5.060 \%$, 12.860 to $17.840 \%$, and -0.545 to $-0.657^{\circ} \mathrm{C}$, respectively, for the SCC, fat, total protein, lactose, total solids, and freezing point. For each variable examined, we processed 3600 analytical data. 
Table 1. Experimental groups to which aliquots taken from 40 goat milk samples were assigned (45 aliquots per sample).

\begin{tabular}{lcl}
\hline & $\begin{array}{l}\text { Storage } \\
\text { temperature }\end{array}$ & Sample age (h/d post-collection) \\
\hline 11 Aliquots without preservative & $4^{\circ} \mathrm{C}$ & $24 \mathrm{~h}$ and $3,5,7,10$, and $13 \mathrm{~d}^{1}$ \\
& $-20^{\circ} \mathrm{C}$ & $21,42,63,84$, and $105 \mathrm{~d}$ \\
17 Aliquots preserved with azidiol & $4^{\circ} \mathrm{C}$ & $24 \mathrm{~h}$, and $3,5,7,10,13,16,20,25,31,37$, and $42 \mathrm{~d}$ \\
& $-20^{\circ} \mathrm{C}$ & $21,42,63,84$, and $105 \mathrm{~d}$ \\
17 Aliquots preserved with bronopol & $4^{\circ} \mathrm{C}$ & $24 \mathrm{~h}$ and $3,5,7,10,13,16,20,25,31,37$, and $42 \mathrm{~d}$ \\
& $-20^{\circ} \mathrm{C}$ & $21,42,63,84$, and $105 \mathrm{~d}$ \\
\hline
\end{tabular}

${ }^{1}$ Samples were not considered after d 13.

\section{Statistical Analyses}

Statistical analysis was carried out using the GLM procedure implemented in the SAS 6.11 software package (1996). In the model applied, the effect of the goat was random, and the remaining effects were fixed such that

$$
\mathrm{Y}_{\mathrm{ijkl}}=\mu+\mathrm{G}_{\mathrm{i}}+\mathrm{S}_{\mathrm{j}}+\mathrm{P}_{\mathrm{k}}+\mathrm{SP}_{\mathrm{jk}}+\mathrm{A}_{\mathrm{l}(\mathrm{jk})}+\mathrm{e}_{\mathrm{ijk} \mathrm{l}}
$$

where $\mathrm{Y}_{\mathrm{ijkl}}=$ dependent variables for $\operatorname{logSCC}$, fat $(\%)$, total protein (\%), lactose (\%), total solids (\%), and freezing point $\left({ }^{\circ} \mathrm{C}\right) ; \mu=$ mean; $\mathrm{G}_{\mathrm{i}}=$ goat effect (40 levels); $\mathrm{S}_{\mathrm{j}}=$ storage temperature effect (2 levels: $\mathrm{RT}$ and FT); $\mathrm{P}_{\mathrm{k}}=$ preservative effect (3 levels: $\mathrm{NP}, \mathrm{AZ}$, and $\mathrm{BR}$ ); $\mathrm{SP}_{\mathrm{jk}}=$ effect of interaction storage temperature $\times$ preservative; $\mathrm{A}_{1(\mathrm{jk})}=$ effect of milk age within the interaction storage temperature $\times$ preservative (storage times at RT of 24 $\mathrm{h}$ and $3,5,7,10$, and $13 \mathrm{~d}$ for NP and $24 \mathrm{~h}$ and $3,5,7$, $10,13,16,20,25,31,37$, and $42 \mathrm{~d}$ for $\mathrm{AZ}$ and $\mathrm{BR}$; storage times at FT of 21, 42, 63, 84, and $105 \mathrm{~d}$ ); and $\mathrm{e}_{\mathrm{ijkl}}=$ random residual.

\section{RESULTS AND DISCUSSION}

\section{Factors Affecting the SCC in Goat Milk}

The factors goat, storage temperature, preservative, interaction of storage temperature $\times$ preservative, and milk age within the interaction storage temperature $x$ preservative contributed significantly to the observed logSCC variation (Table 2). The least square mean of the logSCC was greater $(P<0.001)$ at RT $(5.862)$ than at FT (5.830) (Table 3), which is in agreement with results previously obtained in cow milk (Barkema et al., 1997) and sheep milk (Martinez et al., 2003). The preservation treatment was also an important variation factor. The highest counts were obtained in milk samples preserved with BR (5.877), and the lowest counts were obtained in samples preserved with AZ (5.803) (Table 4). These findings are consistent with those reported for cow milk (Lee et al., 1986; Bertrand, 1996), sheep milk (Gonzalo et al., 2003, 2004), and goat milk (Arcuri et al., 2004). A plausible effect of BR on SCC was discussed by Ardö (1982), who suggested that BR makes possible a greater penetration of ethidium bromide into the cells given stronger florescent signals in the Fossomatic cell counter. The interaction of preservative $\times$ storage temperature also significantly affected the variation in the SCC. Freezing the milk samples gave rise to a significantly reduced logSCC for the AZ and NP treatments, but in samples preserved with BR, freezing did not modify the logSCC values (Table 5), as observed in sheep milk (Martinez et al., 2003). Previous findings indicate overestimation of the SCC in NP samples, possibly because of bacterial growth (Gonzalo et al., 2003). The similar counts obtained here for NP and BR samples

Table 2. ANOVA of variations in the logSCC and milk composition variables.

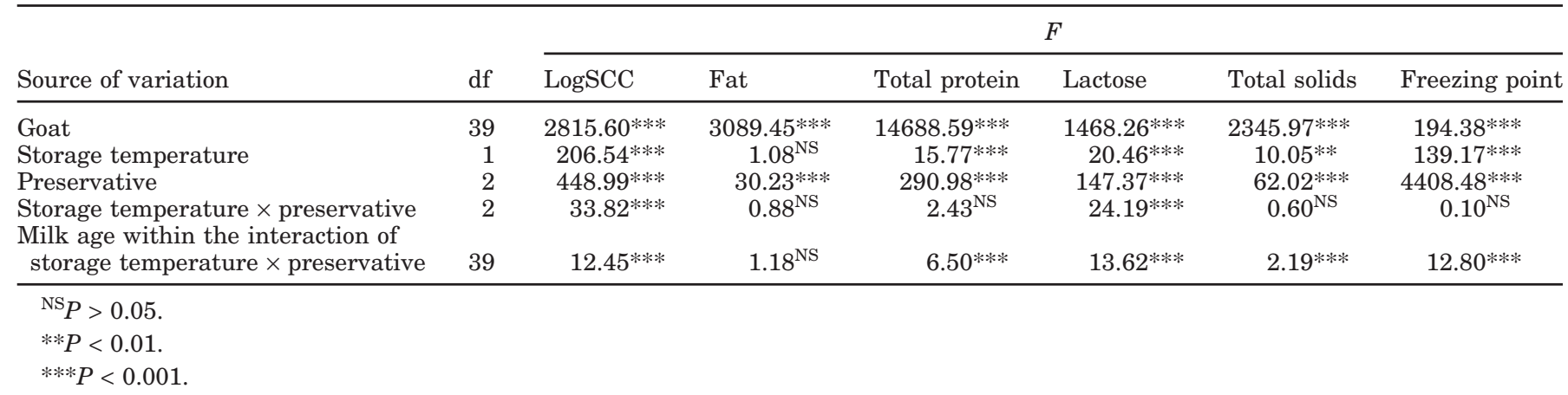


Table 3. Least square means and standard errors of the dependent variables ${ }^{1}$ by storage temperature.

\begin{tabular}{lccccc}
\hline & \multicolumn{2}{c}{ Freezing } & & \multicolumn{2}{c}{ Refrigeration } \\
\cline { 2 - 3 } \cline { 5 - 6 } & LSM & SE & & LSM & SE \\
\hline LogSCC & $5.830^{\mathrm{a}}$ & 0.0017 & & $5.862^{\mathrm{b}}$ & 0.0013 \\
SCC $^{2}$ & 676 & & & 728 & \\
Total protein, \% & $3.563^{\mathrm{a}}$ & 0.0009 & & $3.556^{\mathrm{b}}$ & 0.0007 \\
Lactose, \% & $4.675^{\mathrm{a}}$ & 0.0012 & & $4.668^{\mathrm{b}}$ & 0.0009 \\
Total solids, \% & $14.577^{\mathrm{a}}$ & 0.0054 & & $14.599^{\mathrm{b}}$ & 0.0040 \\
Freezing point, ${ }^{\circ} \mathrm{C}$ & $-0.576^{\mathrm{a}}$ & 0.0001 & & $-0.578^{\mathrm{b}}$ & 0.0001 \\
\hline
\end{tabular}

${ }^{\mathrm{a}, \mathrm{b}}$ Means with different superscripts in a row differ significantly $(P<0.001)$.

${ }^{1}$ Only variables significantly affected by storage temperature.

${ }^{2}$ Geometric mean $\left(\times 10^{3} / \mathrm{mL}\right)$.

stored at RT (Table 5) probably reflect low bacterial loads in the original samples.

The effect of milk age within the interaction of storage temperature $\times$ preservative reveals the changes produced in the SCC for the different test conditions (Figures 1 and 2). At RT, there were no differences in logSCC for the NP samples from $24 \mathrm{~h}$ post-collection until d 13 , when the milk samples underwent spoilage. The logSCC for the preserved milk samples declined steadily throughout the study period. For the BR samples at RT, relative decreases in the geometric means of the SCC from storage times of $24 \mathrm{~h}$ to 10,25 , or $42 \mathrm{~d}$ post-collection were $5,6.9$, and $15 \%$, respectively. These reductions were greater for the $\mathrm{AZ}$ samples stored at $\mathrm{RT}$, with corresponding decreases of 5.8, 15.2, and 21.9\% recorded for the same times post-collection (Figure 1). Previous studies have indicated a large decline in the SCC with age for preserved milk stored at ambient temperature (Kennedy et al., 1982). In BR-preserved sheep milk stored at RT (Gonzalo et al., 2003), SCC values fell by $2.8 \%$ from $3 \mathrm{~h}$ to $9 \mathrm{~d}$ post-collection. Cow milk samples preserved with $\mathrm{BR}$ and stored for longer periods at RT underwent a mean decrease in the SCC of $10 \%$ at 6 wk and $16 \%$ at 10 wk post-collection (Vermunt et al., 1995). The present BR-preserved goat milk samples stored at FT showed no variation in the $\operatorname{logSCC}$ during the study, and $\mathrm{AZ}$ and NP samples showed scarce variation (Figure 2). This observation has also been reported for frozen-stored cow (Barkema et al., 1997) and sheep milk (Martinez et al., 2003). Consistent with the SCC described by Gonzalo et al. (2004) based on flow cytometry, we used the SCC obtained at $24 \mathrm{~h}$ post-collection in BR-preserved samples stored at RT as a reference value. Accordingly, under these conditions, we observed a relative decrease ranging from 4 to $7 \%$ in the geometric mean of the SCC for BR-preserved samples at all the post-collection times considered at FT and up to $25 \mathrm{~d}$ at RT. One decrease lower than $10 \%$ has been considered with little significance in the practical interpretation of the SCC (Schmidt Madsen, 1979), but this variation could have some economic effects as the milk bonus payment using SCC.

\section{Factors Affecting the Composition of Goat Milk}

The sources of variation in the goat milk components examined are provided in Table 2 . The preservation treatment was the main factor affecting all of the variables studied. Highest $(P<0.05)$ percentages of total protein, lactose, and total solids were observed in the BR-preserved samples; the AZ-preserved samples showed the lowest values for these variables $(P<0.05)$. The freezing point was lower $(P<0.05)$ in the BR-treated samples than in those containing AZ. Preservative-free samples showed intermediate levels of total protein, lactose, and total solids relative to the preserved samples (Table 4). These observations are consistent with results obtained in cow milk, in which BR-preserved samples showed higher protein levels than untreated samples (Lee et al., 1986) or those preserved using potassium dichromate (Bertrand, 1996). Similar fat levels were detected in samples containing no preservative or BR; the AZ-preserved samples showed the least amount of fat (Table 4). In cow milk, a higher fat level was observed in BR-preserved samples compared with those without a preservative (Lee et al., 1986). However, this effect

Table 4. Least square means and standard errors of the dependent variables by preservation treatment.

\begin{tabular}{|c|c|c|c|c|c|c|}
\hline & \multicolumn{2}{|c|}{ Azidiol } & \multicolumn{2}{|c|}{ Bronopol } & \multicolumn{2}{|c|}{ No preservative } \\
\hline & LSM & $\mathrm{SE}$ & LSM & $\mathrm{SE}$ & LSM & $\mathrm{SE}$ \\
\hline LogSCC & $5.803^{\mathrm{a}}$ & 0.0018 & $5.877^{\mathrm{b}}$ & 0.0018 & $5.858^{\mathrm{c}}$ & 0.0020 \\
\hline $\mathrm{SCC}^{1}$ & 635 & & 753 & & 721 & \\
\hline Fat, \% & $5.352^{\mathrm{a}}$ & 0.0045 & $5.396^{\mathrm{b}}$ & 0.0045 & $5.396^{\mathrm{b}}$ & 0.0051 \\
\hline Total protein, $\%$ & $3.541^{\mathrm{a}}$ & 0.0010 & $3.574^{\mathrm{b}}$ & 0.0010 & $3.565^{\mathrm{c}}$ & 0.0011 \\
\hline Lactose, \% & $4.655^{\mathrm{a}}$ & 0.0012 & $4.686^{\mathrm{b}}$ & 0.0012 & $4.673^{\mathrm{c}}$ & 0.0014 \\
\hline Total solids, \% & $14.538^{\mathrm{a}}$ & 0.0056 & $14.622^{b}$ & 0.0056 & $14.603^{\mathrm{c}}$ & 0.0064 \\
\hline Freezing point, ${ }^{\circ} \mathrm{C}$ & $-0.577^{\mathrm{a}}$ & 0.0001 & $-0.590^{b}$ & 0.0001 & $-0.564^{\mathrm{c}}$ & 0.0002 \\
\hline
\end{tabular}

a,b,c Means with different superscripts in a row differ significantly $(P<0.05)$.

${ }^{1}$ Geometric mean $\left(\times 10^{3} / \mathrm{mL}\right)$. 
Table 5. Least square means and standard errors of the dependent variables ${ }^{1}$ by storage temperature $\times$ preservative treatment.

\begin{tabular}{lllllll}
\hline $\begin{array}{l}\text { Storage } \\
\text { temperature }\end{array}$ & Preservative & LogSCC & SE & SCC $^{2}$ & Lactose (\%) & SE \\
\hline Freezing & Azidiol & $5.783^{\mathrm{a}}$ & 0.0030 & 607 & $4.656^{\mathrm{ac}}$ & 0.0021 \\
& Bronopol & $5.874^{\mathrm{b}}$ & 0.0030 & 748 & $4.685^{\mathrm{b}}$ & 0.0021 \\
& None & $5.834^{\mathrm{c}}$ & 0.0030 & 682 & $4.684^{\mathrm{b}}$ & 0.0021 \\
Refrigeration & Azidiol & $5.823^{\mathrm{d}}$ & 0.0019 & 665 & $4.655^{\mathrm{a}}$ & 0.0013 \\
& Bronopol & $5.881^{\mathrm{be}}$ & 0.0019 & 760 & $4.687^{\mathrm{b}}$ & 0.0013 \\
& None & $5.882^{\mathrm{e}}$ & 0.0027 & 762 & $4.661^{\mathrm{c}}$ & 0.0019 \\
\hline
\end{tabular}

a,b,c,d,e Means with different superscripts in the same column differ significantly $(P<0.05)$.

${ }^{1}$ Only variables significantly affected by temperature $\times$ preservation.

${ }^{2}$ Geometric mean $\left(\times 10^{3} / \mathrm{mL}\right)$.

has not been observed in milk preserved with potassium dichromate (Ng-Kwai-Hang and Hayes, 1982).

The storage temperature had a significant effect on all variables except fat (Table 2). In cow milk, BR-preserved frozen-stored samples show lower fat percentages (Lee et al., 1986), but we observed no such effect. Despite an effect of the storage temperature on the lactose content (Table 3), effects of the interaction preservation treatment $\times$ storage temperature revealed that the change in the lactose content was independent of the storage temperature in preserved samples. In contrast, NP samples stored at FT showed a higher proportion of lactose $(P<0.05)$ than those stored at RT (Table 5). During storage at RT, lactose levels in the BR-preserved samples remained unchanged. When we examined the effect of milk age within the interaction of storage temperature $\times$ preservative, it was possible to observe the changes experienced by each component in the different test conditions. Bronopol is currently of widespread use in dairy laboratories, replacing other preservation strategies (Be-

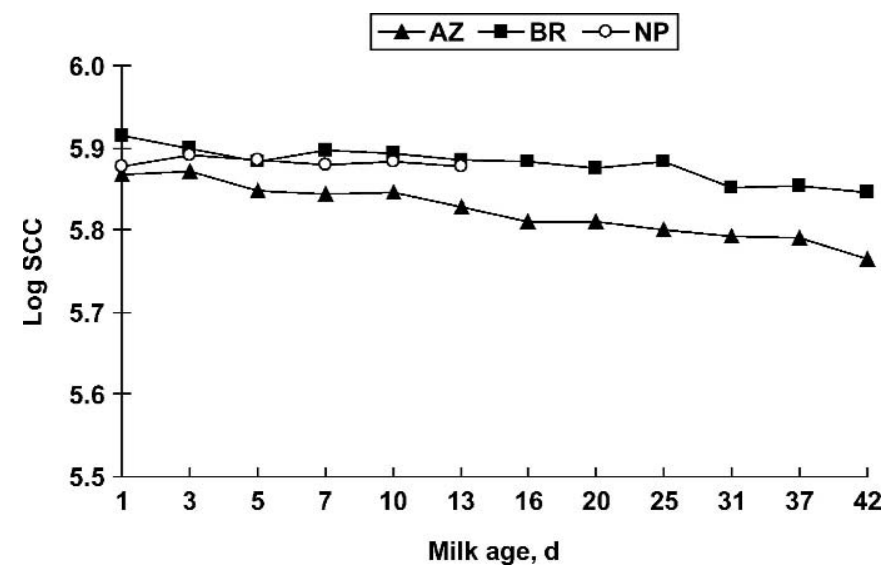

Figure 1. Least square means of the logSCC throughout the study period according to the preservation treatment [azidiol (AZ), bronopol (BR), or no preservative (NP)] of milk samples stored at refrigeration temperature $(\mathrm{SEM}$ of $\mathrm{LSM}=0.0068)$. rtrand, 1996). Given that the preservative used accounted for most of the compositional variation observed, we considered as reference the levels of each constituent recorded in milk samples stored at RT for $24 \mathrm{~h}$ after collection and preserved with BR. Reference percentages of total protein and total solids for the BR-preserved samples did not vary significantly from those obtained at all of the storage times at FT. Neither did the proportions of these components significantly vary among these storage times. Similarly, BR-preserved milk samples stored at RT showed no significant differences in total protein and total solid percentages recorded from 1 to $42 \mathrm{~d}$ post-collection.

The lower $(P<0.05)$ freezing point of preserved samples compared with NP samples can be explained by the chemical nature of the preservatives used (Table 4). Despite the effect of the storage temperature on freezing point (Table 2), the least squares means obtained at $24 \mathrm{~h}$ were similar for frozen and refrigerated samples, regardless of the preservation treatment. Szijarto and van de Voort (1983) obtained a mean freezing point of

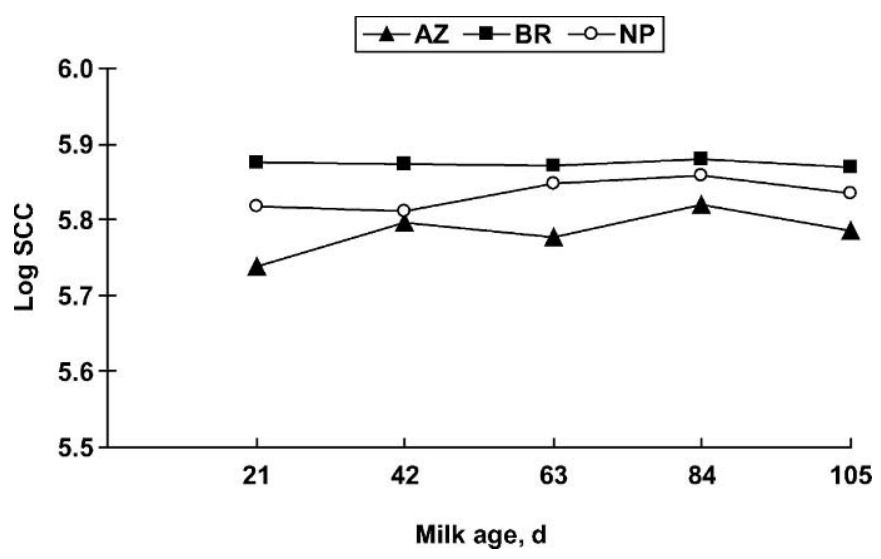

Figure 2. Least square means of the logSCC throughout the study period according to the preservation treatment [azidiol (AZ), bronopol (BR), or no preservative (NP)] in milk samples stored at freezing temperature (SEM of LSM $=0.0068$ ). 
-0.5527 using fresh herd samples of goat milk and calculated a 5 to 6 milli- ${ }^{\circ} \mathrm{C}$ increase in the freezing point for each percentage unit of added water. In the present study, regardless of the preservative used, the freezing point decreased slightly $(P<0.05)$ during storage at RT (by 6 milli- ${ }^{\circ} \mathrm{C}$ for preserved and NP samples at 25 and $13 \mathrm{~d}$ post-collection, respectively). However, in milk samples stored frozen, freezing points remained constant throughout the study period. This effect of the preservative on the freezing point of goat milk should be considered when checking for possible water adulteration.

\section{CONCLUSIONS}

The use of BR provided the best results for the different test conditions examined, suggesting the suitability of several temperature/storage time combinations. Considering that a SCC variation $<10 \%$ is acceptable for monitoring both udder health and the bulk tank SCC, goat milk samples preserved with BR could be stored at $\mathrm{RT}$ for as long as $25 \mathrm{~d}$. For longer periods of storage (from 25 to $105 \mathrm{~d}$ ), goat milk samples treated with $\mathrm{BR}$ could be frozen. Under these conditions, the SCC and fat, total protein, lactose, and total solid contents can all be determined using the same milk sample. The freezing point of goat milk must be established according to the preservative used. Finally, despite the scarce significance of variations attributable to storage temperature, preservation treatment, and age of the sample, the effects of these factors should nevertheless be taken into account for intra- and inter-laboratory quality control.

\section{ACKNOWLEDGMENTS}

The authors thank Francisco Moya Salas for help with collecting samples and $\mathrm{M}^{\mathrm{a}}$ Angeles Giner Benedicto from the Laboratorio Agroalimentario y de Sanidad Animal, Consejería de Agricultura y Agua, Comunidad Autónoma de la Región de Murcia for technical assistance. This study was partly supported by the Instituto Nacional de Investigación y Tecnología Agraria y Alimentaria (INIA), project CAL00-046-C3-2.

\section{REFERENCES}

Arcuri, E. F., P. D. L. Silva, J. R. F. Brito, M. R. Silva, and G. N. Souza. 2004. Use of Somacount 300, calibrated with cow milk standard, for somatic cell count in goat milk. Cienc. Rural 34:1497-1500.
Ardö, Y. 1982. Bronopol as a preservative in milk samples for the determination of cell content using Fossomatic. Milchwissenschaft 37:139-142.

Barcina, Y., M. A. Zorraquino, J. Pedauye, G. Ros, and F. Rincon. 1987. Azidiol as a preservative for milk samples. An. Vet. (Murcia) 3:65-69.

Barkema, H. W., J. Van Der Schans, Y. H. Schukken, A. L. W. De Gee, T. J. G. M. Lam, and G. Benedictus. 1997. Effect of freezing on somatic cell count of quarter milk samples as determined by a Fossomatic electronic cell counter. J. Dairy Sci. 80:422-426.

Bertrand, J. A. 1996. Influence of shipping container, preservative, and breed on analysis of milk components of shipped samples. J. Dairy Sci. 79:145-148.

Corrales, J. C., A. Sánchez, C. Luengo, J. B. Poveda, and A. Contreras. 2004. Effect of clinical contagious agalactia on the bulk tank milk somatic cell count in Murciano-Granadina goat herds. J. Dairy Sci. 87:3165-3171.

Dulin, A. M., M. J. Paape, and W. P. Wergin. 1982. Differentiation and enumeration of somatic cells in goat milk. J. Food Prot. 45:435-439.

Gonzalo, C., J. C. Boixo, J. A. Carriedo, and F. San Primitivo. 2004. Evaluation of rapid somatic cell counters under different analytical conditions in ovine milk. J. Dairy Sci. 87:3623-3628.

Gonzalo, C., J. R. Martínez, J. A. Carriedo, and F. San Primitivo. 2003. Fossomatic cell-counting on ewe milk: comparison with direct microscopy and study of variation factors. J. Dairy Sci. 86:138-145.

Horner, S. D., and L. K. Fox. 1988. Comparison of somatic cell counting procedures for goat milk. J. Dairy Sci. 71(Suppl. 1):164. (Abstr.)

Kennedy, B. W., M. S. Sethar, A. K. W. Tong, J. E. Moxley, and B. R. Downey. 1982. Environmental factors influencing test-day somatic cell counts in Holsteins. J. Dairy Sci. 65:275-280.

Lee, K. L., K. P. Dayton, G. Kroll, and M. L. McGilliard. 1986. Effects of preservative, storage time, and storage temperature on milkfat percent, protein percent and somatic cell count determination. J. Dairy Sci. 69(Suppl. 1):211. (Abstr.)

Luengo, C., A. Sánchez, J. C. Corrales, C. Fernández, and A. Contreras. 2004. Influence of intramammary infection and noninfectious factors on somatic cell counts in dairy goats. J. Dairy Res. 71:169-174.

Martinez, J. R., C. Gonzalo, J. A. Carriedo, and F. San Primitivo. 2003. Effect of freezing on Fossomatic cell counting in ewe milk. J. Dairy Sci. 86:2583-2587.

Miller, R. H., M. J. Paape, and J. C. Acton. 1986. Comparison of milk somatic cell counts by Coulter and Fossomatic counters. J. Dairy Sci. 69:1942-1946.

Ng-Kwai-Hang, K. F., and J. F. Hayes. 1982. Effects of potassium dichromate and sample storage time on fat and protein by MilkoScan and on protein and casein by a modified Pro-Milk Mk II method. J. Dairy Sci. 65:1895-1899.

Paape, M. J., B. Poutrel, A. Contreras, J. C. Marco, and A. V. Capuco. 2001. Milk somatic cells and lactation in small ruminants. J. Dairy Sci. 84(Suppl. E):E237-E244.

SAS/STAT Software. 1996. Changes and Enhancements Through Release 6.11. SAS Inst., Inc., Cary, NC.

Schmidt Madsen, P. 1979. Influence of storage and preservation of milk samples on microscopic and Fossomatic somatic cell counts. Nord. Vet. Med. 31:449-454.

Szijarto, L., and F. R. van de Voort. 1983. Determination of added water and bovine milk to caprine milk. J. Dairy Sci. 66:620-623.

Vermunt, A. E. M., G. J. M. Loeffen, H. van der Voet, and M. A. A. M. Naber. 1995. Development of reference samples for calibration and quality control of somatic cell count using a Fossomatic instrument. Neth. Milk Dairy J. 49:111-123.

Zeng, S. S., E. N. Escobar, S. P. Hart, L. Hinckley, M. Baulthaus, G. T. Robinson, and G. Jahnke. 1999. Comparative study of the effects of testing laboratory, counting method, storage and shipment on somatic cell counts in goat milk. Small Rumin. Res. 31:103-107. 